\title{
Broken Rice for Production of Functional Ice Cream
}

\author{
Fawzia, H. R. Abd Rabo ${ }^{1}$ and Omaima, M. Dewidar ${ }^{2}$ \\ ${ }^{1}$ Department of Dairy Science, Faculty of Agriculture, Cairo University, Egypt \\ 2 Department of Crops Technology Research, Food Technology Research Institute, \\ Agricultural Research Center, Giza, Egypt
}

Received: $17 / 10 / 2017$

\begin{abstract}
Broken rice is a by-product from rice milling industry. The aim of this study was to prepare buffalo skim milk - broken rice milk blends for ice cream production. Ice cream mixtures were standardized to contain $8 \%$ fat, $8 \%$ SNF, $15 \%$ sugar and $0.5 \%$ lacta 9060 . Broken rice milk was used to replace 25, 50, 75 and 100\% of fresh skimmed milk. All mixes and the resultant ice cream samples were evaluated for their physio-chemical and chemical properties as well as the sensory quality attributes. The production costs of different treatments were also studied. The results indicated that the physio-chemical and chemical properties of all mixes were significantly affected. The overrun decreased while, the melting resistance of ice-cream samples significantly increased with increasing the proportion of broken rice milk in the blend. The sensory evaluation results showed that the most acceptable treatments were those made by replacing 25 and $50 \%$ of skim milk with broken rice milk. From the data obtained it could be recommended that ice cream can be produced with high quality by substitution buffalo skim milk with broken rice milk up to $50 \%$ with $17 \%$ reduction in the cost. Production of ice cream free approximately from lactose can be manufactured with up to $34 \%$ reduction in the cost by full substitution of buffalo skim milk with broken rice milk.
\end{abstract}

Keywords: Broken rice, buffalo skim milk, ice cream, cream

\section{INTRODUCTION}

Ice cream is a frozen combination of milk components, sweeteners, stabilizers, emulsifiers and flavours. It is defined as partially frozen foam containing 40 to $50 \%$ air by volume (Larson and Friberg, 1990).

Ice cream is a nutritious, healthful and relatively inexpensive food that supplies per $100 \mathrm{~g}$ approximately 196.7 calories, $4.1 \mathrm{~g}$ protein, $0.122 \mathrm{~g}$ calcium, $0.105 \mathrm{~g}$ phosphorus, 442.8 IU vitamin A, $0.04 \mathrm{mg}$ thiamine and $0.23 \mathrm{mg}$ riboflavin (Arbuckle, 1986). The quality of ice cream depends upon the ingredients used; suitable stabilizers are the most important.

Nowadays, consumers are interested in low cost healthy dairy products (functional dairy products). Preparation of functional ice cream has been studied by several investigators. A novel low fat ice cream based on the use of cactus pear pulp was investigated by ELSamahy et al. (2015). They mentioned that cactus fruit pulp improved the rheological characteristics, the antioxidant activity and the total acceptability of the low fat ice cream. The use of avocado fruit pulp (AFP) as functional ingredients rich in natural antioxidants and high content of unsaturated fatty acids in the manufacture of ice cream was investigated by Khalil and Blassy (2015). They found that the use of AFP up to $15 \%$ can be recommended in developing a new low fat ice cream of high antioxidant scavenging activity and acceptable sensory properties.

Novel functional low fat ice cream flavoured with roasted date seed (RDS) was studied by Khalil et al. (2016). They reported that RDS could potentially be an inexpensive source for cocoa/coffee flavour substitute and possibly used as a functional food ingredients.

Broken rice is a by-product of rice milling industry. It is a very good source of carbohydrates but low in fat. Broken rice could be used as an important ingredient for manufacture of many low cost, low lactose and low fat dairy products. Carbohydrates of rice are predominantly starch with small portions of pentosan, hemicelluloses and sugars. Rice protein has one of the highest nutritive values among cereal proteins because of its high lysine content (Bandyopadhyay and Roy, 1992). Rice protein has a comparatively high content of essential amino acids with high total digestibility of protein (Pillaiyar, 1988).

Therefore, this study was undertaken to investigate the effect of using broken rice milk in ice cream production pertaining of the properties of the resultant ice cream as well as the cost of its production.

\section{MATERIALS AND METHODS}

\section{Materials}

Fresh buffalo skim milk (0.5\% fat and $9 \%$ S.N.F) and fresh cream $(65 \%$ fat and $6 \%$ S.N.F) were obtained from the Dairy Technology Unit, Dairy Science Department, Faculty of Agriculture, Cairo University, Egypt. Sugar and vanilla were obtained from the local market in Cairo. Lacta 9060 (combination of selected emulsifiers and stabilizers blends) was obtained from Misr Food Additives (MIFAD). Broken rice was obtained from Crops Research Institute, Agriculture Research Center, Ministry of Agriculture, Giza, Egypt.

\section{Preparation of ice cream mixtures}

Formulation: Ice cream mixtures were prepared from the formentioned ingredients with quantities calculated as shown in Table (1). Ice cream mixtures were standardized to contain $8 \%$ fat, $8 \%$ S.N.F, $15 \%$ sugar and $0.5 \%$ lacta 9060 . Broken rice milk was used to replace $25,50,75$ and $100 \%$ of fresh skimmed milk. 


\section{Preparation of broken rice milk}<smiles>O=C(Cl)C1CCCC1Br</smiles>

\section{Cleaning}<smiles>C1CCCC1</smiles>

Soaking (2 h)<smiles>C1CCCC1</smiles>

Draining<smiles>C1CCCC1</smiles>

Cooking (1:3) /30 min<smiles>C1CCCC1</smiles>

Blending with water<smiles>C1CCCC1</smiles>

Broken rice milk (0.6\%fat and 8.72 S.N.F)

\section{Process of manufacture}

- Accurately weighed dry ingredients were mixed with liquid ingredients by means of manual stirring for 10 minutes to get uniform mixture.

- Mixtures were heat treated at $80^{\circ} \mathrm{C}$ for 15 minutes.

- Mixtures were cooled down and stored at $4{ }^{\circ} \mathrm{C}$ for 6 hours for ageing.

- After ageing vanilla flavour was added to the mixes before freezing in a horizontal batch freezer (Batch ice cream maker "STARMATICV500", Italy). The frozen ice cream was drawn in plastic cups $(120 \mathrm{ml})$ and hardened at $-26^{\circ} \mathrm{C}$ for $24 \mathrm{~h}$ before analysis.

- All treatments were of three replicates.

\section{Methods of analysis}

Total solids, fat, total protein, lactose and ash were determined according to AOAC (2007). The carbohydrates content was determined by subtracting the sum of fat, protein, lactose and ash from total solids. Titratable acidity of mixes was determined in duplicate according to Richardson (1986) by titration with $\mathrm{NaOH}$ $0.1 \mathrm{~N}$. Values of $\mathrm{pH}$ were measured using a digital laboratory $\mathrm{pH}$ meter (HI 931400, Hanna instruments) with glass electrode. Overrun of ice cream samples was calculated according to Marshall et al. (2003) as the difference in volume between resultant ice cream and original mix. Melting rate of the resultant ice cream samples was determined as mentioned by Segall and Goff (2002). Ice cream samples were allowed to melt at room temperature $\left(23 \pm 1^{\circ} \mathrm{C}\right)$ and the melted portion was weighed every $10 \mathrm{~min}$. The percent mass loss $/ \mathrm{min}$ in the linear region (slope) was used to compare the meltdown rate of different samples.

Viscosity was determined using a coaxial rotational viscometer (Rheotest II, Medingen, Germany) at shear rates ranging from 3.0 to $1312 \mathrm{~s}^{-1}$. The measuring device (S1) was used with a sample volume of $30 \mathrm{ml}$ per run. All samples were adjusted to $20 \pm 1^{\circ} \mathrm{C}$ before loading in the viscometer device. Apparent viscosity was calculated at shear rate of $48.6 \mathrm{~s}^{-1}$.

\section{Sensory evaluation}

All the ice cream samples were sensory rated for flavuor (45), body \& texture (30), melting properties (10) and colour (15) by 12 panelists of experienced staff members at Dairy Science Department, Cairo University and Agriculture Research Center, Ministry of Agriculture, Giza, Egypt.

\section{Statistical analysis}

The data (mean of three replicates) were analyzed by the General Linear Models procedure of SAS (1996). Least significant difference test was performed to determine differences in means at $\mathrm{P} \leq 0.05$.

Table (1): Ingredients (\%) of different ice cream recipes $(\mathrm{Kg} / 100 \mathrm{Kg}$ mix)

\begin{tabular}{|c|c|c|c|c|c|}
\hline Ingredients \% & $\mathbf{T}_{1}$ & $\mathbf{T}_{2}$ & $\mathbf{T}_{3}$ & $\mathbf{T}_{4}$ & $\mathbf{T}_{5}$ \\
\hline Sugar & 15 & 15 & 15 & 15 & 15 \\
\hline Lacta 90-60 & 0.50 & 0.50 & 0.50 & 0.50 & 0.50 \\
\hline Fresh skim milk & 72.80 & 54.60 & 36.40 & 18.20 & - \\
\hline Cream & 11.70 & 11.70 & 11.70 & 11.70 & 11.70 \\
\hline Broken rice milk & - & 18.20 & 36.40 & 54.60 & 72.80 \\
\hline Total & 100 & 100 & 100 & 100 & 100 \\
\hline
\end{tabular}

$\mathrm{T}_{1}: 100 \%$ skim milk + zero broken rice milk, $\mathrm{T}_{2}: 75 \%$ skim milk $+25 \%$ broken rice milk

$\mathrm{T}_{3}: 50 \%$ skim milk $+50 \%$ broken rice milk, $\mathrm{T}_{4}: 25 \%$ skim milk $+75 \%$ broken rice milk

$\mathrm{T}_{5}$ : zero $\%$ skim milk $+100 \%$ broken rice milk 


\section{RESULTS AND DISCUSSION}

\section{Properties of ice cream mixes}

Physico-chemical properties and chemical composition of different ice cream mixes are shown in Tables (2) and (3). Titratable acidity values tended to slightly decrease and the $\mathrm{pH}$ values increased with increasing the proportion of broken rice milk in the blend (Table 2). These differences may be due to the changes of protein and ash content of the mixes (Table 3). Natural titratable acidity in milk and milk products is dependent on casein, albumin, phosphates, citrates and carbon dioxide as mentioned by Atherton and Newlander (1977).

Viscosity is considered as an important aspect for proper whipping and retention of air cells. The viscosity of experimental mixes progressively increased with increasing the proportion of broken rice milk in the blend. Viscosity ranged from $86 \pm 1.5$ to $176 \pm 1.0 \mathrm{cp}$ (Table 2). In this respect Cottrell et al. (1980) mentioned that polysaccharides such as starch are reported to increase the mix viscosity.
Similar results were obtained by Awad (2007). He mentioned that the apparent viscosity of ice cream mixes significantly increased with substitution of skim milk powder by rice flour.

Chemical composition of ice cream mixes prepared from different blends of buffalo skim milk broken rice milk is shown in Table (3). There were notecible differences in the total solids and fat contents of ice cream mixes. These differences may be due to differences in the quantity and chemical composition of broken rice milk and skim milk.

Total protein, lactose and ash contents of ice cream mixes were significantly decreased with increasing the proportion of broken rice milk in the blend. On the other hand, the total carbohydrates content was increased as the proportion of broken rice milk increased.

Awad (2007) reported that all mixes with rice flour had lower protein and ash contents and the values were decreased with increasing the add ratio of rice flour instead of skim milk powder in the formula. Carbohydrates content, on the other hand was increased as the substitution increased.

Table (2): Physico-chemical properties of different ice cream mixes

\begin{tabular}{lccc}
\hline & & Properties & \\
Treatments* & $\mathbf{p H}$ & Acidity\% & Apparent Viscosity (cp) \\
\hline $\mathbf{T}_{\mathbf{1}}$ & $6.56 \pm 0.40^{\mathrm{d}}$ & $0.23 \pm 0.015^{\mathrm{a}}$ & $86.0 \pm 1.5^{\mathrm{e}}$ \\
$\mathbf{T}_{\mathbf{2}}$ & $6.63 \pm 0.26^{\mathrm{c}}$ & $0.23 \pm 0.02^{\mathrm{a}}$ & $96.0 \pm 1.0^{\mathrm{d}}$ \\
$\mathbf{T}_{\mathbf{3}}$ & $6.69 \pm 0.006^{\mathrm{b}}$ & $0.20 \pm 0.02^{\mathrm{a}}$ & $110.0 \pm 1.0^{\mathrm{c}}$ \\
$\mathbf{T}_{\mathbf{4}}$ & $6.83 \pm 0.017^{\mathrm{a}}$ & $0.21 \pm 0.01^{\mathrm{a}}$ & $138.0 \pm 0.8^{\mathrm{b}}$ \\
$\mathbf{T}_{\mathbf{5}}$ & $6.86 \pm 0.052^{\mathrm{a}}$ & $0.20 \pm 0.025^{\mathrm{a}}$ & $176.0 \pm 1.0^{\mathrm{a}}$ \\
\hline L.S.D & 0.064 & 0.031 & 1.97 \\
\hline
\end{tabular}

*See Table (1) for details

Means in the same column having different superscript letters are significantly different $p \leq 0.05$

Table (3): Chemical composition (\%) of different ice cream mixes

\begin{tabular}{|c|c|c|c|c|c|c|}
\hline Treatments* & T.S & Protein & Fat & Ash & Lactose & Carbohydrates \\
\hline $\mathbf{T}_{1}$ & $30.67 \pm 0.06^{\mathrm{c}}$ & $3.26 \pm 0.11^{\mathrm{a}}$ & $8.11 \pm 0.05^{\mathrm{d}}$ & $0.616 \pm 0.001^{\mathrm{a}}$ & $4.064 \pm 0.0075^{\mathrm{a}}$ & $14.611 \pm 0.792^{d}$ \\
\hline $\mathbf{T}_{2}$ & $30.50 \pm 0.05^{\mathrm{d}}$ & $2.32 \pm 0.00^{b}$ & $8.31 \pm 0.03^{b}$ & $0.48 \pm 0.001^{b}$ & $3.220 \pm 0.070^{b}$ & $16.179 \pm 1.005^{\mathrm{cd}}$ \\
\hline $\mathbf{T}_{3}$ & $30.98 \pm 0.02^{\mathrm{a}}$ & $1.96 \pm 0.09^{c}$ & $8.40 \pm 0.01^{\mathrm{a}}$ & $0.423 \pm 0.008^{c}$ & $2.316 \pm 0.283^{c}$ & $17.880 \pm 1.010^{\mathrm{bc}}$ \\
\hline $\mathbf{T}_{4}$ & $30.61 \pm 0.02^{\mathrm{c}}$ & $1.15 \pm 0.11^{\mathrm{d}}$ & $8.20 \pm 0.03^{c}$ & $0.382 \pm 0.011^{\mathrm{d}}$ & $1.243 \pm 0.266^{\mathrm{d}}$ & $19.621 \pm 1.005^{b}$ \\
\hline $\mathbf{T}_{5}$ & $30.83 \pm 0.03^{\mathrm{b}}$ & $0.078 \pm 0.0^{\mathrm{e}}$ & $8.19 \pm 0.02^{c}$ & $0.317 \pm 0.005^{\mathrm{e}}$ & $0.042 \pm 0.008^{\mathrm{e}}$ & $22.203 \pm 1.001^{\mathrm{a}}$ \\
\hline L.S.D & 0.067 & 0.141 & 0.033 & 0.012 & 0.3008 & 1.758 \\
\hline
\end{tabular}

*See Table (1) for detail

Means in the same column having different superscript letters are significantly different $p \leq 0.05$ 
The overrun and melting resistance results of the resultant ice cream are shown in Figs (1 and 2). The overrun in ice cream is directly related with the yield and profit. The overrun differed significantly among the treatments as shown in Fig (1). Control ice cream had the maximum (i.e. $88 \%$ ) overrun whereas $\mathrm{T}_{5}$ had the least overrun (i.e. 55\%). Patel et al. (2006) stated that the more the protein, the more the protienious bubbles trapping air inside and resulting in high overrun.
Melting rate as influenced by the proportion of buffalo skim milk- broken rice milk has been given in Fig (2). It can be notice from the results that the melting resistance of ice cream samples significantly increased with the addition of broken rice milk. The higher viscosity of experimental mixes (Table 2) might be partly responsible for low melting rate of the treatments.

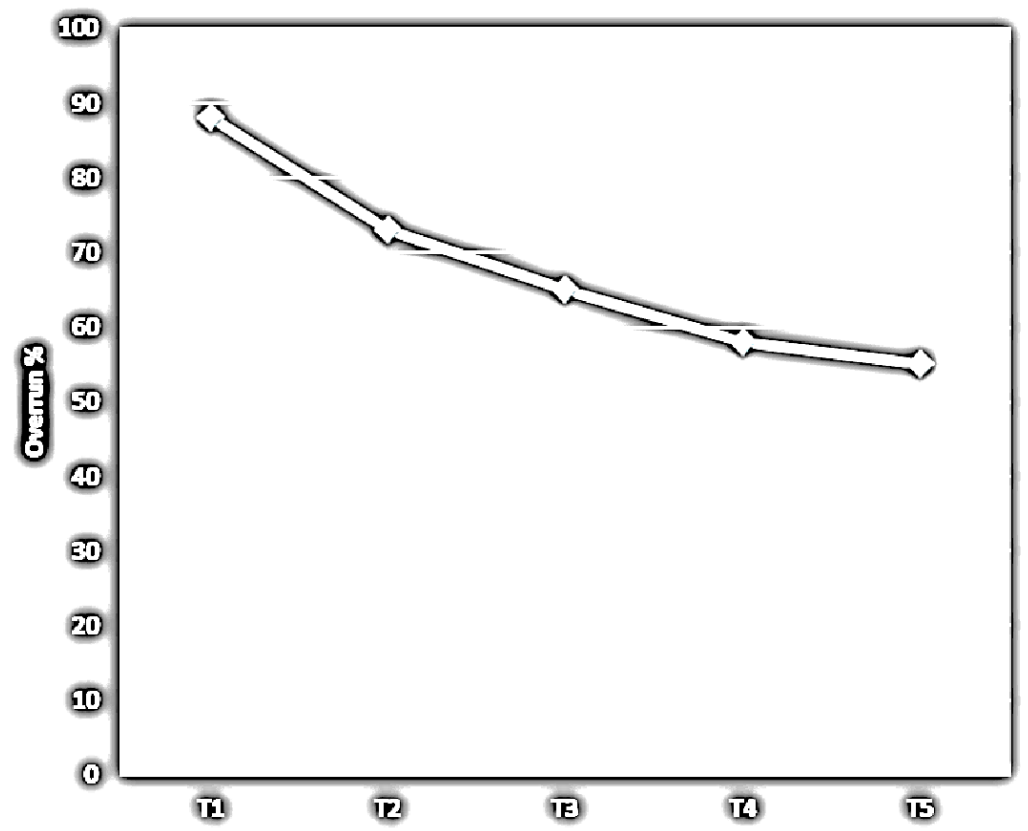

Fig. (1): The overrun of the resultant ice cream

$\mathrm{T}_{1}: 100 \%$ skim milk + zero broken rice milk; $\mathrm{T}_{2}: 75 \%$ skim milk $+25 \%$ broken rice milk; $\mathrm{T}_{3}: 50 \%$ skim milk $+50 \%$ broken rice milk; $\mathrm{T}_{4}: 25 \%$ skim milk $+75 \%$ broken rice milk; $\mathrm{T}_{5}$ : zero $\%$ skim milk $+100 \%$ broken rice milk

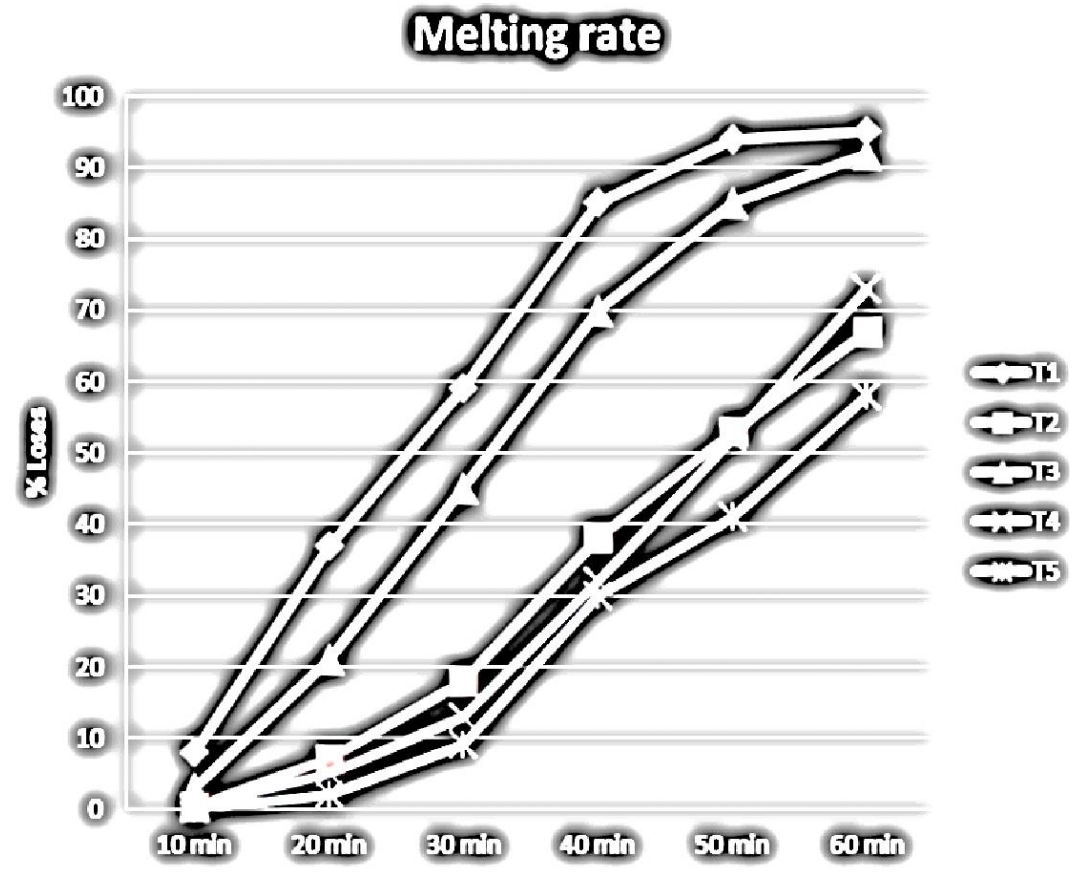

Fig. (2): Melting rate of the resultant ice cream

$\mathrm{T}_{1}: 100 \%$ skim milk + zero broken rice milk; $\mathrm{T}_{2}: 75 \%$ skim milk $+25 \%$ broken rice milk; $\mathrm{T}_{3}: 50 \%$ skim milk $+50 \%$ broken rice milk; $\mathrm{T}_{4}: 25 \%$ skim milk $+75 \%$ broken rice milk; $\mathrm{T}_{5}:$ zero $\%$ skim milk $+100 \%$ broken rice milk 


\section{Sensory evaluation}

The resultant ice cream samples prepared from different blends of skim milk and broken rice milk were subjected to sensory evaluation for overall acceptability attributes by panelists.

Results in Table (4) indicated that as the proportion of broken rice milk increased the overall acceptability scores of the resultant ice cream decreased. Statistically, there was no significant difference between the different treatments except $T_{5}$ in flavour which had the lowest score compared with other treatments. However, the most acceptable treatments were $T_{2}$ and
$\mathrm{T}_{3}$ (those made by replacing 25 and $50 \%$ of skim milk with broken rice milk) as reported by the panelists.

\section{Production costs}

Production costs of different ice cream recipes were calculated and presented in Table (5).

Data obtained showed that the cost reduction (\%) remarkably increased as the proportion of broken rice milk increased in the blend. As shown the approximately free lactose ice cream treatment can be manufactured with up to $34.0 \%$ reduction in the cost by full substitution of buffalo skim milk with broken rice milk.

Table (4): Sensory evaluation of the resultant ice cream

\begin{tabular}{lccccc}
\hline Treatments* $^{*}$ & $\begin{array}{c}\text { Flavour } \\
\mathbf{( 4 5 )}\end{array}$ & $\begin{array}{c}\text { Body Texture } \\
\mathbf{( 3 0 )}\end{array}$ & $\begin{array}{c}\text { Melting properties } \\
\mathbf{( 1 0 )}\end{array}$ & $\begin{array}{c}\text { Colour } \\
\mathbf{( 1 5 )}\end{array}$ & $\begin{array}{c}\text { Total score } \\
(\mathbf{1 0 0})\end{array}$ \\
\hline $\mathbf{T}_{\mathbf{1}}$ & $43.35 \pm 1.84^{\mathrm{a}}$ & $28.0 \pm 1.87^{\mathrm{a}}$ & $8.81 \pm 1.35^{\mathrm{a}}$ & $14.62 \pm 0.87^{\mathrm{a}}$ & $94.77 \pm 4.11^{\mathrm{a}}$ \\
$\mathbf{T}_{\mathbf{2}}$ & $41.69 \pm 2.17^{\mathrm{a}}$ & $27.88 \pm 2.12^{\mathrm{a}}$ & $8.88 \pm 1.12^{\mathrm{a}}$ & $14.46 \pm 0.75^{\mathrm{a}}$ & $92.92 \pm 4.47^{\mathrm{a}}$ \\
$\mathbf{T}_{\mathbf{3}}$ & $42.31 \pm 2.53^{\mathrm{a}}$ & $27.81 \pm 2.39^{\mathrm{a}}$ & $9.31 \pm 0.95^{\mathrm{a}}$ & $14.12 \pm 0.77^{\mathrm{a}}$ & $93.53 \pm 5.33^{\mathrm{a}}$ \\
$\mathbf{T}_{\mathbf{4}}$ & $40.69 \pm 2.89^{\mathrm{a}}$ & $27.15 \pm 2.23^{\mathrm{a}}$ & $8.73 \pm 1.05^{\mathrm{a}}$ & $14.35 \pm 0.94^{\mathrm{a}}$ & $90.92 \pm 4.55^{\mathrm{a}}$ \\
$\mathbf{T}_{\mathbf{5}}$ & $37.59 \pm 5.55^{\mathrm{b}}$ & $26.58 \pm 3.35^{\mathrm{a}}$ & $8.77 \pm 1.17^{\mathrm{a}}$ & $13.96 \pm 1.39^{\mathrm{a}}$ & $86.91 \pm 8.08^{\mathrm{a}}$ \\
\hline L.S.D & 2.66 & 1.92 & 0.89 & 0.76 & 9.41 \\
\hline
\end{tabular}

*See Table (1) for details

Means in the same column having different superscript letters are significantly different $p \leq 0.05$

\section{CONCLUSION}

As the objective of the present study was to use the maximum level of broken rice milk to manufacture acceptable product, the combination of 50:50 buffalo skim milk - broken rice milk can be recommended. In other words, as there is a great deal of attention has been focused on functional food production such as low or free lactose products, utilization of higher percentage of broken rice milk as an ingredient in ice cream formulation $\left(\mathrm{T}_{4}\right.$ and $\mathrm{T}_{5}$ ) may lead to production of inexpensive healthy food with up to $25.5 \%$ and $34 \%$ reduction in the cost respectively.

Table (5): Production costs of different treatments (L.E./100Kg mix)

\begin{tabular}{|c|c|c|c|c|c|}
\hline \multirow{2}{*}{ Ingredients } & \multicolumn{5}{|c|}{ Treatments* } \\
\hline & $\mathbf{T 1}$ & $\mathbf{T} 2$ & T3 & T4 & T5 \\
\hline Sugar & 150 & 150 & 150 & 150 & 150 \\
\hline Lacta 90-60 & 30 & 30 & 30 & 30 & 30 \\
\hline Fresh skim milk & 364.0 & 273.0 & 182.0 & 91.0 & - \\
\hline Cream & 526.5 & 526.5 & 526.5 & 526.5 & 526.5 \\
\hline Broken rice milk & - & - & - & - & - \\
\hline Total costs & 1040.5 & 979.5 & 888.5 & 797.5 & 706.5 \\
\hline Cost reduction \% & - & 8.5 & 17.0 & 25.5 & 34.0 \\
\hline
\end{tabular}

\footnotetext{
*See Table (1) for details
} 


\section{ACKNOWLEDGMENT}

The authors of this study thank Dr. Mohamed Abd EL Gany EL Asar, professor of Dairy Science, Faculty of Agriculture Cairo University for his effort provided through this work.

\section{REFERENCES}

AOAC (2007). AOAC Official Methods of Analysis, $18^{\text {th }}$ ed. AOAC, Washington, DC.

Arbuckle, W. S. (1986). Ice cream, $4^{\text {th }}$ ed. AVI Publishing Company, Inc. Westport, Connecticut, pp 326-362.

Atherton, V. H. and J. A. Newlander (1977). Chemistry and Testing of Dairy Products AVI Pub Ico. Ink. Westport. CT.

Awad, R. A. (2007). Performance of rice flour in ice cream manufacture. Proc $10^{\text {th }}$ Egyptian Conf. Dairy Sci. Technol., 517- 534.

Bandyopadhyay, S. and N. C. Roy (1992). Rice Process Technology, Oxford \& IBH Publishing Co., New Delhi, India.

Cottrell, J. I. L., G. Pass and G. O. Phillips (1980). The Effect of stabilizers on the viscosity of icecream Mix. J. Food Sci. Agric., 31: 10661070.

El-Samahy, S.K.; Gaballah, A.A.; Embaby, H.E.; Hamed, Y.S. and Khalil, R.A.M. (2015). Producing novel low fat ice cream using substantial amounts of Cactus fruit (Opuntia dillenii) pulp. Egyptian J. Dairy Sci., 43: 91104.

Khalil, R. A. M and K. I. Blassy (2015). Development of low fat ice cream flavoured with avocado fruit pulp. Egyptian Journal of Dairy Sci., 43: 177-188.

Khalil, R. A. M and K. I. Blassy (2016). Novel functional low fat ice cream flavoured with roasted date seed. Egyptian Journal of Dairy Sci., 44: 137-149.

Larson, K. and S. E. Friberg (1990). Food Emulsion. The Shahid, S. H. (2000). Preparation of ready to drink soymilk AVI Pub. Co., USA.

Marshall, R. T., H. D. Goff and R. W. Hartel (2003). Ice cream, $6^{\text {th }}$ edn. Kluwer Academic/Plenum Publisher, NY.

Patel, M. R., R. J. Baer and M. R. Acharya (2006). Increasing the protein content of ice cream. Journal of Dairy Science, 89: 1400-1406.

Pillaiyar, P. (1988). Rice Post production Manual. Wiley Eastern limited, New Delhi, India.

Richardson, H. G. (1986). Standard methods for the examination of dairy Products, $15^{\text {th }}$ edn. Amr. Public Health Assoc, Washington.

SAS (1996). SAS/STAT1 User's Guide, Version 8. SAS Inst, Inc, Cary, NC.

Segall, K. I. and H. D. Goff (2002). A modified ice cream processing routine that promotes fat destabilization in the absence of added emulsifier. International Dairy Journal, 12: 10131018 .

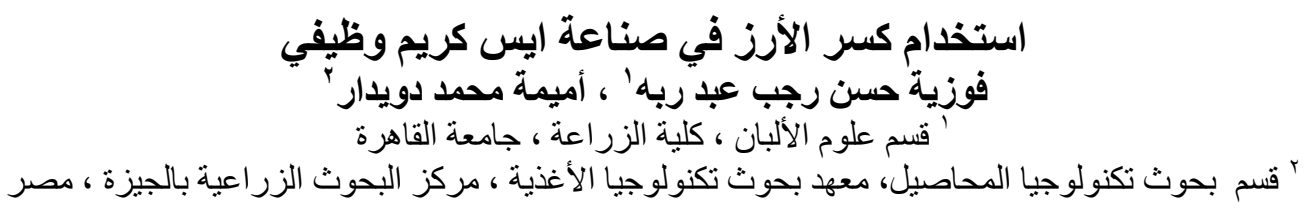

كسر الأرز هو المنتج الثانوي الناتج من عملية تبييض محصول الأرز. تهدف هذه الدراسة إلى إعداد خليط من اللبن الجاموسي

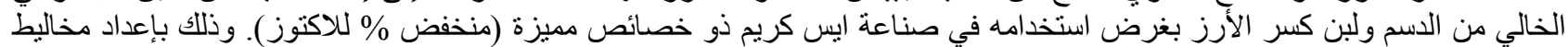

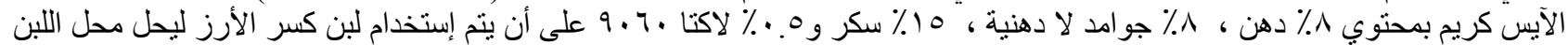

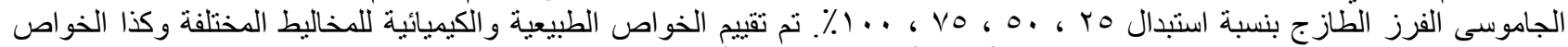

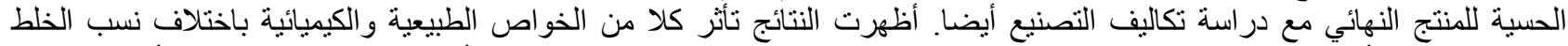

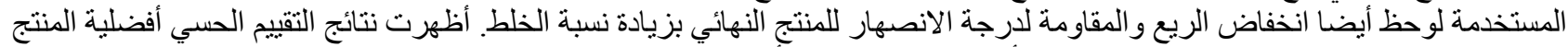

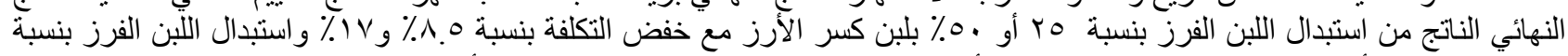

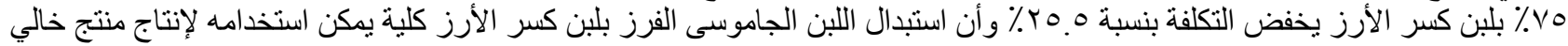
اللاكتوز تقريبا وبتكلفة اقل بمقدار عب الإز 